\title{
KARAKTERISTIK FISIKO-KIMIA DAN FUNGSIONAL PATI SAGU IHUR TERMODIFIKASI DENGAN HEAT MOISTURE TREATMENT
}

\author{
[Physicochemical and Functional Characterization of Modified Ihur Sago Starch \\ by Heat Moisture Treatment]
}

\author{
Priscillia Picauly"), Esau Damamain ${ }^{1)}$, dan Febby J. Polnaya ${ }^{1,2) \star}$ \\ 1) Jurusan Teknologi Hasil Pertanian, Fakultas Pertanian, Universitas Pattimura, Ambon \\ 2) Pusat Studi Ilmu Pangan, Universitas Pattimura, Ambon
}

Diterima 15 November 2016 / Disetujui 17 Maret 2017

\begin{abstract}
The objective of this study was to characterize the properties of Heat Moisture treatment (HMT) modified ihur sago starch with different moisture contents. The starch was modified with $\mathrm{HMT}$ at $110^{\circ} \mathrm{C}$ after being adjusted to various moisture contents $(23,28$, or 33\%) for $4 \mathrm{~h}$. The physico-chemical and functional properties of the native and modified HMT Ihur sago starch observed were color, swelling power, solubility, paste clarity, moisture content, ash content, amylose content, phenol content, and resistant starch (RS) content. Results of this study showed that the HMT starch has a higher degree of lightness $\left(L^{*}\right)$, redness $\left(a^{*}\right)$, and yellowness $\left(b^{*}\right)$, solubility $(4.85-5.38 \%)$ but lower swelling power $(44.06$ $47.47 \mathrm{~g} / \mathrm{g}$ ) than the native starch which has a solubility and swelling power of $4.90 \%$ and $50.72 \mathrm{~g} / \mathrm{g}$, respectively. Paste clarity was found to decrease along the storage period. In addition, higher moisture content (11.81-13.20\%), but lower amylose (14.81-23.52\%), phenol (2.50-4.04\%), and RS (5.4-6.1\%) content were observed than the native starch with amylose, phenol, and RS content of 27.18, 7.91, and $6.5 \%$, respectively.
\end{abstract}

Keywords: heat moisture treatment, ihur sago starch, pysico-chemical properties, resistant starch

\section{ABSTRAK}

Penelitian ini bertujuan mengkarakteristik pati sagu ihur modifikasi Heat Moisture Treatment (HMT) dengan kadar air yang berbeda. Pati dimodifikasi dengan $\mathrm{HMT}$ pada $110^{\circ} \mathrm{C}$ setelah diatur variasi kadar air $(23,28$, atau $33 \%)$ selama 4 jam. Pengamatan dilakukan terhadap sifat fisiko-kimia dan fungsional pati sagu alami dan HMT seperti warna, kemam puan menggelembung, daya larut, kejernihan pasta, kadar air, kadar abu, kadar amilosa, kadar fenol, dan kadar pati resisten (RS). Hasil penelitian menunjukkan bahwa warna pati sagu alami memiliki nilai $L^{*}, a^{*}$, dan $b^{*}$ yang lebih tinggi dibandingkan dengan pati HMT, kemampuan menggelembung pati HMT $(44,06-47,47 \mathrm{~g} / \mathrm{g})$ lebih rendah dibandingkan pati alami $(50,72$ $\mathrm{g} / \mathrm{g}$ ), daya larut pati HMT (4,85-5,38\%) relatif lebih rendah dari pati alami (4,90\%), kejernihan pasta pati HMT mengalami penurunan nilai selama proses penyimpanan, kadar air pati HMT $(11,81-13,20 \%)$ lebih tinggi dari pati alami, kadar amilosa pati HMT (14,81-23,52\%) lebih rendah dari pati alami $(27,18 \%)$, kadar fenol pati HMT (2,50-4,04\%) lebih rendah dari pati alami (7,91\%), dan kadar RS HMT (5,4-6,1\%) lebih rendah dibanding pati alami $(6,5 \%)$.

Kata kunci: heat moisture treatment, pati resisten, pati sagu ihur, sifat-sifat fisiko-kimia

\section{PENDAHULUAN}

Sagu merupakan salah satu komoditi tanaman pangan sumber karbohidrat yang potensial yang terdiri dari lima jenis yaitu sagu tuni, sagu ihur, sagu molat, sagu makanaru dan sagu duri rotan. Warna pati sagu umumnya berwarna putih, namun ada juga secara genetik berwarna kemerahan yang disebab-

*Penulis Korespondensi:

E-mail: febbyjpolnaya@yahoo.com kan oleh senyawa fenolik yang terdapat pada jenis sagu ihur (Metroxylon silvester) (Purwani et al., 2006). Pati sagu dapat diaplikasikan secara luas dalam berbagai industri dan sangat tergantung pada sifat fisiko-kimia dan fungsionalnya.

Penggunaan pati alami, termasuk pati sagu ihur terbatas oleh sifat fisiko-kimianya seperti retrogradasi, sineresis, kestabilan, dan ketahanan pasta yang rendah terhadap $\mathrm{pH}$ dan perubahan suhu. Sifat fisiko-kimia dan fungsional dari pati sagu dapat ditingkatkan dengan cara modifikasi pati. Setiap 
metode modifikasi pati menghasilkan pati termodifikasi dengan sifat fisiko-kimia yang berbedabeda. Salah satu teknik modifikasi fisik pati yang dapat digunakan yaitu modifikasi heat moisture treatment (HMT).

Modifikasi pati HMT dilaporkan dapat memperbaiki karakteristik profil gelatinisasi pati, lebih stabil terhadap proses pemanasan, perlakuan mekanis, dan tingkat keasaman dengan meningkatkan suhu gelatinisasi dan menurunkan kapasitas menggelembung granula (Pranoto et al., 2014). Modifikasi HMT dilakukan dengan kadar air terbatas (kurang dari $35 \%$ air) dipanaskan pada kondisi di atas suhu transisi glas tetapi masih di bawah suhu gelatinisasinya selama periode waktu tertentu. HMT menyebabkan perubahan konformasi molekul pati dan menghasilkan struktur kristalin yang lebih resisten terhadap proses gelatinisasi (Pukkahuta dan Varavinit, 2007).

Beberapa penelitian menunjukkan bahwa modifikasi HMT dapat memengaruhi karakteristik sifat fisiko-kimia shorgum, pati resisten (resistant starch, RS) kacang hijau, pati beras, dan pati ubi kayu (Li et al., 2011; Puncha-arnon dan Uttapap, 2013). Modifikasi HMT memengaruhi sifat daya larut dan kemampuan menggelembung dari pati sorgum (Olayinka et al., 2008). Intensitas perubahan dipengaruhi oleh kondisi pati dan kondisi proses seperti kadar air, suhu, dan waktu (Syamsir et al., 2012). Sudah dilaporkan modifikasi HMT pati sagu dengan mengatur kadar air awal 25\% (Purwani et al., 2006) dan kadar air awal 20\% (Pukkahuta dan Varavinit, 2007), namun belum ada publikasi tentang modifikasi HMT pada pati sagu ihur dengan perlakuan kadar air awal yang berbeda.

Tujuan penelitian ini untuk mengkarakteristik pati sagu ihur modifikasi HMT dengan pengaturan kadar air awal berbeda, meliputi warna, kemampuan menggelembung, daya larut, kejernihan pasta, kadar air, kadar abu, amilosa, fenol dan kadar RS.

\section{BAHAN DAN METODE}

\section{Bahan}

Bahan utama yang digunakan dalam penelitian ini adalah pati sagu ihur. Pati sagu tersebut merupakan hasil ekstraksi petani lokal di Negeri Alang, Kabupaten Maluku Tengah.

\section{Metode penelitian}

Penelitian untuk menghasilkan sagu pati ihur modifikasi HMT dengan mengatur kadar air awal pati sagu, yaitu $\mathrm{HMT}_{23}=23 \%, \mathrm{HMT}_{28}=28 \%$ atau $\mathrm{HMT}_{33}=33 \%$. Sebagai pembanding digunakan pati sagu alami. Pati HMT yang dihasilkan dianalisis warna, kemampuan menggelembung dan daya larut (Adebowale et al., 2009), kejernihan pasta (Walis- zewski et al., 2003), kadar air (AOAC, 2007), kadar abu (AOAC, 2007), kadar amilosa (AOAC, 1984), kadar fenol (Rodriguez-Carpena et al., 2011), dan kadar RS (AOAC, 2007).

\section{Modifikasi HMT pati sagu}

Pati sagu ihur hasil ekstraksi petani dibersihkan di laboratorium. Pati sagu kemudian disimpan di dalam wadah plastik high-density polyethylene (HDPE) sampai dengan saat digunakan untuk dimodifikasi ataupun dianalisis. Modifikasi pati sagu ihur dengan teknik HMT mengacu pada metode Collado dan Corke (1999). Pati sagu yang sudah diketahui kadar air awalnya ditimbang sebanyak 200 g, kemudian diatur kadar airnya dengan disemprot akuades sampai mencapai kadar air sesuai dengan perlakuan $(23,28$ atau 33\%). Jumlah akuades ditentukan berdasarkan perhitungan kesetimbangan masa. Pati sagu yang telah ditentukan kadar airnya diekuilibrasi pada suhu $4^{\circ} \mathrm{C}$ selama 12 jam. Pati sagu dipanaskan dalam wadah stainless steel tertutup dengan menggunakan oven konveksi (Memmert, Germany) pada suhu $110^{\circ} \mathrm{C}$ selama 4 jam. Selama perlakuan pemanasan, dilakukan pengadukan pati secara periodik setiap jam. Untuk menurunkan kadar air, pati sagu HMT kemudian dikeringkan dengan suhu $50^{\circ} \mathrm{C}$ selama 4 jam. Pati sagu HMT dihaluskan dan diayak kembali sehingga diperoleh pati yang lolos ayakan 60 mesh. Pati sagu HMT selanjutnya disimpan dalam wadah plastik HDPE.

\section{Analisis kadar air}

Analisis kadar air mengacu pada AOAC (1984). Sebanyak $1 \mathrm{~g}$ sampel pati dimasukkan dalam botol timbang yang telah diketahui beratnya. Sampel dipanaskan dalam oven (Memmert, Germany) pada suhu $105^{\circ} \mathrm{C}$ sampai didapat berat tetap. Kadar air sampel didasarkan pada perbedaan berat sampel sebelum dan sesudah dikeringkan.

\section{Analisis kadar abu}

Analisis kadar abu mengacu pada AOAC (1984). Sebanyak $5 \mathrm{~g}$ sampel pati dimasukkan dalam cawan porselin yang telah dikeringkan dan diketahui beratnya. Sampel dibakar dengan pemanas listrik sampai sampel tidak berasap dan diabukan pada tanur pengabuan (Vulcan A-550 Ney, USA) pada suhu $650^{\circ} \mathrm{C}$ sampai dihasikan abu yang berwarna putih keabu-abuan dan beratnya telah konstan. Kadar abu sampel ditentukan dengan menimbang sisa mineral hasil pembakaran bahan organik.

\section{Analisis kadar amilosa}

Analisis kadar amilosa pati mengacu pada AOAC (1984). Sebanyak $100 \mathrm{mg}$ sampel pati ditempatkan ke dalam tabung reaksi $50 \mathrm{~mL}$. Setelah 
itu ditambahkan $1 \mathrm{~mL}$ etanol 95\% (Sigma-Aldrich, Germany) dan $9 \mathrm{~mL} \mathrm{NaOH} 1 \mathrm{M}$ (Merck, Germany) lalu dihomogenkan dengan divortex. Campuran dipanaskan dalam penangas air mendidih selama 10 menit, kemudian diencerkan hingga $100 \mathrm{~mL}$. Sebanyak $5 \mathrm{~mL}$ larutan sampel dimasukkan ke dalam labu takar $100 \mathrm{~mL}$ dan ditambahkan dengan $1 \mathrm{~mL}$ larutan asam asetat $1 \mathrm{~N}$ (Merck, Germany) dan 2 $\mathrm{mL}$ larutan lod 0,01 N (Merck, Germany), dan akuades sampai batas tera. Larutan dipanaskan dengan penangas air pada suhu $30^{\circ} \mathrm{C}$ selama 20 menit. Intensitas warna biru yang terbentuk diukur absorbansinya dengan UV-Vis spektrofotometer (Genesys $10 \mathrm{~S}$, China) pada $\lambda 620 \mathrm{~nm}$. Absorbansi yang diperoleh diplotkan pada kurva standar dan kadar amilosa dihitung berdasarkan hubungan absorbansi sampel dengan kurva standar.

\section{Analisis warna}

Analisis warna dilakukan dengan menggunakan Chromameter CR 300 Minolta (Japan). Uji dialkukan dengan sistem warna Hunter $L^{*}, a^{*}, b^{*}$. Chromameter terlebih dahulu dikalibrasi dengan standar warna putih yang terdapat pada alat tersebut.

\section{Analisis kemampuan menggelembung dan daya larut pati}

Analisis kemampuan menggelembung dan daya larut pati mengacu pada metode yang dikemukakan oleh Adebowale et al. (2009). Pati dilarutkan dalam air akuades $(1 \%, \mathrm{~b} / \mathrm{v})$ dalam tabung reaksi yang telah diketahui beratnya $\left(W_{1}\right)$. Kemudian dipanaskan pada penangas air (Memmert, Germany) pada suhu $95^{\circ} \mathrm{C}$ selama 30 menit, lalu didinginkan hingga suhu kamar $\left(27^{\circ} \mathrm{C}\right)$. Selanjutnya suspensi pati dipisahkan dengan sentrifugasi (Hermle, Germany) pada $5000 \mathrm{rpm}$ selama 15 menit, sehingga terpisah residu dan supernatan. Residu hasil sentrifugasi kemudian ditimbang $\left(W_{2}\right)$. Kemampuan menggelembung pati (berdasarkan berat kering) ditentukan sebagai berikut:

$$
\text { Kemampuan Menggelembung }(g / g)=\frac{\left(W_{2}-W_{1}\right)}{\text { berat pati }}
$$

Alikuot $(10 \mathrm{~mL})$ dari supernatan dikeringkan hingga berat konstan pada suhu $110^{\circ} \mathrm{C}$. Residu yang terdapat setelah dikeringkannya supernatan, menunjukkan jumlah pati yang terlarut dalam air (\%).

\section{Analisis kejernihan pasta}

Analisis kejernihan pasta pati mengacu pada metode yang dikemukakan oleh Waliszewski et al. (2003). Suspensi pati dibuat dengan konsentrasi $2 \%$ (w/v) dipanaskan pada penangas air dengan suhu $90^{\circ} \mathrm{C}$ selama 30 menit sambil di-shaker. Suspensi didinginkan hingga suhu $\pm 30^{\circ} \mathrm{C}$, kemudian disimpan pada suhu $4^{\circ} \mathrm{C}$ selama 96 jam dan setiap 24 jam dilakukan pengukuran kejernihan pasta didasarkan nilai transmitansi $(\% T)$. Transmitansi diukur dengan spektrofotometer UV-Vis pada $\lambda 650 \mathrm{~nm}$. Sebagai blanko digunakan akuades.

\section{Analisis kadar fenol}

Analisis kadar fenol mengacu pada metode yang dikemukakan oleh (Rodriguez-Carpena et al., 2011). Pati sebanyak $0,5 \mathrm{~g}$ diekstrak dalam $5 \mathrm{~mL}$ pelarut methanol. Selanjutnya diambil ekstrak sebanyak $\pm 0,2 \mathrm{~mL}$ dan ditambahkan $1 \mathrm{~mL}$ reagen folinciocalteu (Merck, Germany) (pengenceran 1:10, $\mathrm{v} / \mathrm{v})$. Kemudian tambahkan $0,8 \mathrm{~mL}$ sodium carbonat $7,5 \%$ (b/v) (Merck, Germany), selanjutnya di vorteks. Ekstrak dibiarkan di ruang gelap selama 30 menit dan diukur absorbansinya pada $\lambda 725 \mathrm{~nm}$. Kurva standar dibuat menggunakan asam galat (SigmaAldrich, USA) (gallic acidequivalent) dengan konsentrasi $0 ; 0,02 ; 0,04 ; 0,06 ; 0,08$ dan $0,1 \mathrm{mg} / \mathrm{mL}$.

\section{Analisis kadar pati resisten}

Analisis kadar pati resisten mengacu pada metode AOAC (2007). Sampel sebanyak $1 \mathrm{~g}$ disuspensikan dalam $50 \mathrm{~mL}$ larutan buffer fosfat $0,08 \mathrm{M}$ (Merck, Germany), pH 5,5. Kemudian diinkubasi pada suhu $100^{\circ} \mathrm{C}$ sampai tergelatinisasi. Sampel didinginkan pada suhu kamar $\left(27^{\circ} \mathrm{C}\right)$ sampai suhu larutan mencapai $65^{\circ} \mathrm{C}$. Setelah itu, sampel ditambah dengan $10 \mu \mathrm{L}$ enzim $\alpha$-amilase (Megazyme, USA) dan diinkubasi pada suhu $65^{\circ} \mathrm{C}$ selama 30 menit. Setelah diinkubasi, suspensi ditambahkan $\mathrm{HCl} 1 \mathrm{~N}$ (Merck, Germany), sampai tercapai pH 4,5. Pada pH tersebut, ditambahkan $20 \mu \mathrm{L}$ campuran enzim amilo-glukosidase (Megazyme, USA) dan diinkubasikan pada suhu $60^{\circ} \mathrm{C}$ selama 60 menit. Sampel diambil $10 \mu \mathrm{L}$ dan ditambah $1 \mathrm{~mL}$ glukosa oksidase FS berasal dari Diagnostic System Internantional (Holzhein, Germany). Sampel diinkubasi selama 20 menit pada suhu $20-25^{\circ} \mathrm{C}$. Peneraan dilakukan dengan menggunakan spektrofotometer UV-Vis pada $\lambda 500 \mathrm{~nm}$. Kadar RS (\%) dihitung berdasarkan formula sebagai berikut:

$$
\% \text { RS }=\frac{1-G \times 0,9}{\text { berat sampel }} \times 100 \%
$$

Dimana: G merupakan berat glukosa (g); 0,9 adalah faktor konversi (162/180) dari D-glukosa bebas yang ditentukan sebagai D-glukosa pada pati.

\section{Rancangan percobaan}

Penelitian menggunakan rancangan acak lengkap dengan tiga ulangan. Data dianalisis dengan menggunakan program SAS 9.1 dan dilanjutkan dengan uji Tukey pada taraf $95 \% \quad(\alpha=0,05)$ untuk mengetahui perbedaan diantara perlakuan tersebut. 


\section{HASIL DAN PEMBAHASAN}

\section{Warna pati}

Nilai $L^{*}, a^{*}$, dan $b^{*}$ untuk pati sagu ihur alami berturut-turut adalah sebesar 80,76; 8,62; dan 17,91 (Tabel 1), berbeda jika dibandingkan dengan penelitian Polnaya et al. (2009) yaitu 64,67; 5,62; dan 1,87. Perbedaan nilai warna dapat disebabkan karena perbedaan sumber pati ihur atau proses pengolahan pati.

Tabel 1. Karakteristik sifat warna pati sagu ihur alami dan hmt

\begin{tabular}{cccc}
\hline Perlakuan & $\begin{array}{c}\text { Kecerahan } \\
\left(L^{*}\right)\end{array}$ & $\begin{array}{c}\text { Kemerahan } \\
\left(a^{*}\right)\end{array}$ & $\begin{array}{c}\text { Kekuningan } \\
\left(b^{\star}\right)\end{array}$ \\
\hline Pati alami & $80,76 \pm 0,78^{\mathrm{a}}$ & $8,62 \pm 0,15^{\mathrm{a}}$ & $17,91 \pm 0,85^{\mathrm{a}}$ \\
$\mathrm{HMT}_{23}$ & $80,29 \pm 0,63^{\mathrm{a}}$ & $5,26 \pm 0,25^{\mathrm{b}}$ & $14,54 \pm 1,38^{\mathrm{b}}$ \\
$\mathrm{HMT}_{28}$ & $79,44 \pm 0,52^{\mathrm{ab}}$ & $4,70 \pm 0,62^{\mathrm{b}}$ & $14,45 \pm 1,38^{\mathrm{b}}$ \\
$\mathrm{HMT}_{33}$ & $78,62 \pm 0,21^{\mathrm{b}}$ & $4,45 \pm 0,44^{\mathrm{b}}$ & $14,38 \pm 1,35^{\mathrm{b}}$
\end{tabular}

Keterangan: $\mathrm{HMT}=$ Heat Moisture Treatment; ${ }^{\mathrm{a} 0}$ nilai yang diikuti dengan huruf yang sama pada kolom yang sama menunjukkan tidak ada perbedaan nyata berdasarkan uji Tukey pada taraf $\alpha=0,05$

Warna kemerahan pada pati sagu ihur disebabkan karena reaksi pencoklatan yang dikatalisis oleh enzim polifenoloksidase. Reaksi tersebut berlangsung apabila sel mengalami perusakan sehingga fenolik indigenous teroksidasi dan menghasilkan warna kemerahan (Mayer, 1986). Seperti juga yang dikemukakan oleh Purwani et al. (2006), bahwa warna kemerahan pati sagu ihur ditentukan oleh senyawa fenolik. Hasil penelitian menunjukkan bahwa pati sagu ihur mengandung fenolik indigenous sebesar 7,91\% dan lebih tinggi dibandingkan hasil penelitian Lang et al. (2006) yaitu sebesar $<1 \%$. Perbedaan kadar total fenol dapat disebabkan karena perbedaan sumber pati ihur, proses pengolahan pati atau metode analisisnya.

Meningkatnya perlakuan kadar air awal pati HMT menyebabkan menurunnya nilai warna pati HMT (Tabel 1). Namun demikian, nilai kecerahan $\left(L^{*}\right)$ pati alami tidak berbeda nyata dengan pati $\mathrm{HMT}_{23}$ dan $\mathrm{HMT}_{28}$, sedangkan nilai kemerahan $\left(a^{*}\right)$ dan kekuningan $\left(b^{*}\right)$ pati alami berbeda nyata dengan pati HMT. Menurunnya nilai kecerahan pati warna pati tersebut, dapat disebabkan karena reaksi pencoklatan pada saat pemanasan, terutama dipengaruhi oleh komponen non karbohidrat (polifenoloksidase). Kadar air awal pati HMT yang semakin tinggi memudahkan terjadinya reaksi tersebut pada saat pemanasan dilakukan.

\section{Kemampuan menggelembung dan daya larut pati}

Kemampuan menggelembung pati sagu ihur sebesar $50,73 \mathrm{~g} / \mathrm{g}$, lebih rendah jika dibandingkan dengan penelitian Polnaya et al. (2009) sebesar $77,78 \mathrm{~g} / \mathrm{g}$. Hal ini dapat disebabkan karena perbedaan sumber pati ihur yang digunakan dalam penelitian ini. Kemampuan menggelembung pati sagu HMT $(44,06-47,40 \mathrm{~g} / \mathrm{g})$ lebih rendah dibandingkan pati alaminya. Namun demikian, hanya $\mathrm{HMT}_{33}$ menghasilkan kemampuan menggelembung terendah dan berbeda nyata dengan pati alaminya (Tabel 2). Penurunan kemampuan menggelembung pati akibat HMT dilaporkan pada pati jagung (Malumba et al., 2010; Sun et al., 2015), dan sorghum (Olayinka et al., 2008). Penurunan kemampuan menggelembung pati akibat HMT disebabkan karena terjadinya perubahan struktur granula pati yaitu perubahan interaksi antara matriks amorf dan kristalit. Modifikasi HMT dapat menyebabkan molekul amilosa yang terletak pada daerah amorf berinteraksi dengan percabangan dari molekul amilopektin. Seperti juga yang dikemukakan oleh Jiranuntakul et al. (2011) bahwa perlakuan HMT dapat memengaruhi sifat-sifat kristalinitas pati. Peningkatan kadar air awal pati HMT menyebabkan perubahan struktur granula pati lebih lanjut sehingga menurunkan kemampuan menggelembung pati. Tingginya kadar air pati memudahkan mobilisasi molekul heliks ganda, meningkatkan interaksi interdan intra-molekuler granula melalui ikatan hidrogen.

Daya larut pati sagu ihur adalah sebesar $4,86 \%$, lebih rendah jika dibandingkan dengan penelitian Polnaya et al. (2009) sebesar 10,11\%. Hal ini dapat disebabkan karena perbedaan sumber pati ihur yang digunakan dalam penelitian ini. Daya larut pati HMT berkisar antara $4,85-5,38 \%$, relatif lebih tinggi dibandingkan pati alaminya (Tabel 2).

Tabel 2. Karakteristik sifat fisiko-kimia pati sagu ihur alami dan hmt

\begin{tabular}{|c|c|c|c|c|c|c|c|}
\hline Perlakuan & $\begin{array}{c}\text { Kemampuan } \\
\text { Menggelembung } \\
(\mathrm{g} / \mathrm{g})\end{array}$ & $\begin{array}{c}\text { Daya Larut } \\
(\%)\end{array}$ & $\begin{array}{c}\text { Kadar Air } \\
(\%)\end{array}$ & $\begin{array}{c}\text { Kadar Abu } \\
(\%)\end{array}$ & $\begin{array}{c}\text { Amilosa } \\
(\%)\end{array}$ & $\begin{array}{c}\text { Kadar Fenol } \\
(\%)\end{array}$ & $\begin{array}{c}\text { Kadar RS } \\
(\%)\end{array}$ \\
\hline Pati alami & $50,73 \pm 2,90^{a}$ & $4,86 \pm 0,18^{\mathrm{ab}}$ & $11,57 \pm 0,58^{\circ}$ & $0,05 \pm 0,04$ & $27,18 \pm 0,04^{a}$ & $7,91 \pm 1,12^{a}$ & $6,50 \pm 0,72^{a}$ \\
\hline $\mathrm{HMT}_{23}$ & $47,40 \pm 0,86^{\mathrm{ao}}$ & $4,85 \pm 0,09^{D}$ & $11,81 \pm 0,46^{\mathrm{ab}}$ & $0,03 \pm 0,02$ & $22,52 \pm 3,23^{a b}$ & $5,40 \pm 1,42^{\mathrm{ab}}$ & $6,10 \pm 1,21^{\mathrm{ab}}$ \\
\hline $\mathrm{HMT}_{28}$ & $46,59 \pm 0,90^{\mathrm{ab}}$ & $5,35 \pm 0,21^{\text {ao }}$ & $12,13 \pm 0,60^{\mathrm{ao}}$ & $0,02 \pm 0,02$ & $20,94 \pm 4,35^{\text {ao }}$ & $4,04 \pm 1,93^{\mathrm{D}}$ & $5,70 \pm 1,23^{a \mathrm{a}}$ \\
\hline $\mathrm{HMT}_{33}$ & $44,06 \pm 1,54^{D}$ & $5,38 \pm 0,20^{a}$ & $13,21 \pm 0,67^{a}$ & $0,03 \pm 0,02$ & $14,20 \pm 4,30^{\circ}$ & $2,50 \pm 1,31^{\mathrm{D}}$ & $5,40 \pm 1,51^{\mathrm{D}}$ \\
\hline
\end{tabular}

Keterangan: HMT = Heat Moisture Treatment; RS = Resistant Starch; ${ }^{\text {ab }}$ nilai yang diikuti dengan huruf yang sama pada kolom yang sama menunjukkan tidak ada perbedaan nyata berdasarkan uji Tukey pada taraf $\alpha=0,05$ 
Pati $\mathrm{HMT}_{33}$ menunjukkan daya larut tertinggi dan berbeda nyata dengan pati $\mathrm{HMT}_{23}$. Kecenderungan meningkatnya daya larut pati HMT seiring dengan meningkatnya kadar air awal, menunjukkan melemahnya ikatan intermolekul pati. Kadar air awal yang tinggi, dapat menyebabkan lebih mudahnya reformasi struktur amilosa dan amilopektin, sehingga menyebabkan pati $\mathrm{HMT}_{33}$ lebih mudah larut dibandingkan perlakuan lainnya. Haryani et al. (2015) mengemukakan bahwa pengaturan kadar air pada saat memodifikasi pati menggunakan HMT dapat menyebabkan reformasi struktur amilosa dan amilopektin, sehingga granula pati lebih mudah menyerap air dan cenderung meningkatkan sifat kelarutan pati HMT sorghum.

\section{Kejernihan pasta pati}

Kejernihan pasta pati sagu ihur adalah sebesar $58,3 \% T$, lebih tinggi jika dibandingkan dengan penelitian Polnaya et al. (2009) yaitu sebesar $33,26 \% T$. Hal ini dapat disebabkan karena perbedaan sumber pati ihur yang digunakan dalam penelitian ini. Kejernihan pasta pati sagu HMT berkisar antara $38,33-54,30 \% T$ pada jam ke-0 pengukuran, lebih rendah dibandingkan pati alaminya. Kecenderungan yang sama juga ditunjukkan pada pengukuran jam ke-24, 72, dan 96 (Gambar 1). Hasil yang relatif sama juga ditunjukkan oleh Yadav et al. (2013). Hal ini dapat disebabkan karena HMT menyebabkan berubahnya susunan struktur molekul pati yang melibatkan gugus hidroksil di dalam susunan ikatan molekul, sehingga terbentuk lapisan keras pada granula. Lapisan keras tersebut dapat terbentuk akibat meningkatnya rigiditas granula. Hoover dan Manuel (1996) menyatakan bahwa modifikasi HMT dapat meningkatkan ikatan hidrogen intermolekul dan intramolekul yang terbentuk dalam granula pati.

Kejernihan pasta pati dapat digunakan untuk menentukan tendensi retrogradasi pati. Polnaya et al. (2009) mengemukakan bahwa apabila pasta pati dibiarkan mendingin, lama kelamaan akan menjadi buram disebabkan karena proses retrogradasi dan akan dipercepat pada suhu rendah. Berdasarkan pengukuran kejernihan pasta berdasarkan lama penyimpanan pada suhu rendah, diperoleh penurunan tingkat kejernihan pasta pati sagu alami sebesar $31,9 \%$, sedangkan pati sagu $\mathrm{HMT}_{23}, \mathrm{HMT}_{28}$, dan $\mathrm{HMT}_{33}$ adalah berturut-turut sebesar 25,13, 24,57 , dan $28,43 \%$. Meningkatnya persentasi penurunan tingkat kejernihan pati HMT, menunjukkan bahwa perlakuan HMT memudahkan terjadinya retrogradasi. Kadar air awal pati yang tinggi memudahkan terjadinya gesekan molekul air selama pemanasan sehingga memungkinkan degradasi termal pada susunan heliks ganda molekul amilopektin. Degradasi molekul amilopektin meningkatkan molekul amilosa menyebabkan pasta pati lebih menjadi opak dan menurunkan nilai transmitan pati HMT. Rahmayuni (2009) mengemukakan bahwa dengan berubahnya susunan ikatan molekul menyebabkan pati ubi jalar HMT lebih mudah mengalami retrogradasi dibandingkan pati alaminya.

Sifat fisik warna pati menunjukkan kecenderungan yang sama dengan sifat fisik kejernihan pasta pati. Hasil penelitian Polnaya et al. (2009) juga menunjukkan bahwa warna pati yang ditunjukkan oleh nilai $L^{*}$ lebih tinggi, menghasilkan pati dengan tingkat kejernihan yang lebih tinggi jika dibandingkan dengan pati yang nilai $L^{*}$ lebih rendah.

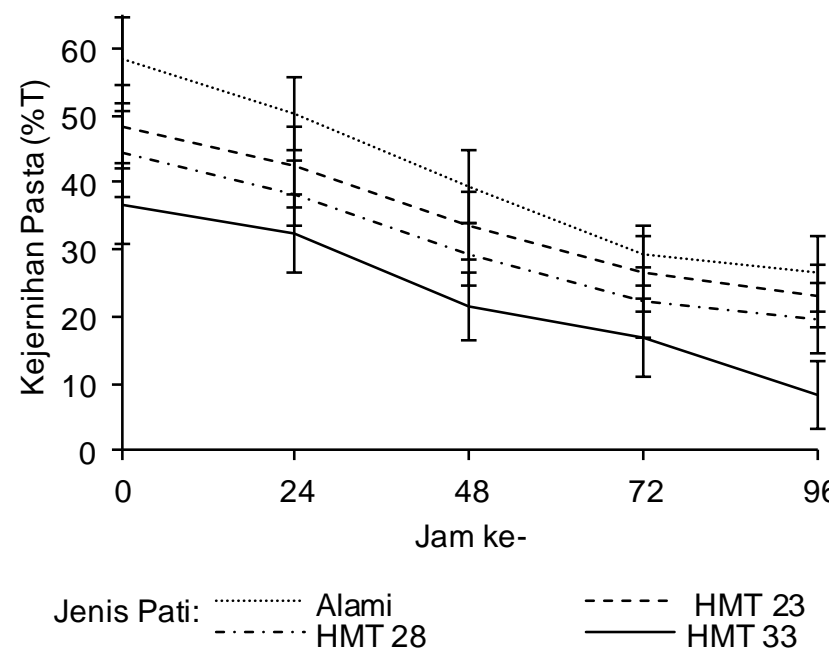

Gambar 1. Kejernihan pasta pati sagu ihur alami dan HMT

\section{Kadar air}

Kadar air pati sagu ihur adalah sebesar $11,57 \%$, lebih rendah jika dibandingkan dengan penelitian Polnaya et al. (2009) yaitu sebesar 12,53\% maupun Purwani (2006) sebesar 17,03\%. Hal ini dapat disebabkan karena perbedaan sumber pati ihur atau proses pengolahan pati. Kadar air pati sagu HMT (11,81-13,21\%) relatif lebih tinggi dibandingkan pati alaminya. Kadar air pati $\mathrm{HMT}_{33}$ menunjukkan nilai tertinggi dan berbeda nyata hanya dengan pati alaminya. Hasil penelitian menunjukkan bahwa semakin tinggi kadar air awal pati HMT akan meningkatkan kadar air akhir pati HMT (Tabel 2). Hal ini disebabkan karena pada kadar air awal yang berbeda tetapi dengan waktu dan suhu pemanasan yang sama, menurunkan jumlah air yang relatif sama. Perbedaan kadar air pati HMT sangat ditentukan oleh perlakuannya. Hasil yang relatif sama juga dikemukakan oleh Andrade et al. (2014) yaitu peningkatan kadar air pati kasava HMT. Seperti yang dikemukakan juga oleh Haryani et al. (2015) bahwa penambahan kadar air pada saat memodifikasi pati menggunakan HMT dapat menyebabkan reformasi struktur amilosa dan amilopektin, sehingga granula pati lebih mudah menyerap air. 


\section{Kadar abu}

Kadar abu pati sagu ihur adalah sebesar $0,05 \%$, lebih rendah jika dibandingkan dengan penelitian Purwani (2006) sebesar 0,26\%. Hal ini dapat disebabkan karena perbedaan sumber pati ihur, proses pengolahan pati atau metode analisis. Kadar abu pati sagu HMT $(0,02-0,03 \%)$ lebih rendah dibandingkan pati alaminya, tetapi berdasarkan uji Tukey antar perlakuan tidak berbeda nyata (Tabel 2). Hasil ini sesuai dengan beberapa penelitian yang melaporkan bahwa kadar abu pati hasil modifikasi dengan teknik HMT lebih rendah dibandingkan pati alami untuk pati pearl millet (Balasubramanian et al., 2014) dan pati kentang (Nadir et al., 2015). Kecenderungan menurunnya kadar abu setelah modifikasi dapat disebabkan karena pemanasan pada suhu tinggi saat modifikasi dapat menyebabkan penurunan nilai kadar abu. Menurut Gunorubon dan Kekpugile (2012), komponen abu mudah mengalami dekomposisi atau bahkan menguap pada suhu tinggi.

\section{Kadar amilosa}

Kadar amilosa pati sagu ihur adalah sebesar $27,18 \%$, lebih rendah jika dibandingkan dengan penelitian Polnaya et al. (2009) yaitu sebesar 35,13\% dan Purwani et al. (2006) yaitu sebesar 37,24\%. Hal ini dapat disebabkan karena perbedaan sumber pati ihur, proses pengolahan pati atau metode analisis. Kadar amilosa pati sagu HMT (14,82-22,52\%) lebih rendah dibandingkan pati alaminya. Kadar amilosa pati $\mathrm{HMT}_{33}$ menunjukkan nilai terendah dan berbeda nyata hanya dengan pati alaminya (Tabel 2). Menurunnya kadar amilosa seiring meningkatkan perlakuan kadar air awal pati disebabkan karena meningkatnya peluruhan (leaching) amilosa seiring dengan meningkatnya kadar air HMT (Singh et al., 2011). Zavareze et al. (2010) mengemukakan bahwa HMT menyebabkan permukaan granula pati beras menjadi tidak beraturan jika dibandingkan dengan pati alaminya.

Menurunnya kadar amilosa pati HMT disebabkan karena teknik modifikasi tersebut memengaruhi permukaan granula pati. Proses pemanasan pati dan keberadaan air saat HMT berlangsung mengakibatkan area amorf pati mengembang, kemudian menekan keluar area berkristal sehingga terjadi kerusakan dan pelelehan area berkristal granula pati. Kadar air awal pati HMT yang tinggi lebih memengaruhi perubahan pola difraksi pati yang dipengaruhi oleh dehidrasi, sehingga memicu pergerakan heliks ganda yang dapat mengakibatkan kerusakan pada kristalit pati dan atau orientasi kristal (Gunaratne dan Hoover, 2002). Hal ini menyebabkan pada kadar air awal pati yang tinggi, menghasilkan kadar amilosa semakin rendah.

\section{Kadar fenol}

Kadar fenol pati sagu HMT (2,50-5,40\%) lebih rendah dibandingkan pati alaminya (7,91\%). Modifikasi $\mathrm{HMT}_{28}$ dan $\mathrm{HMT}_{33}$ menghasilkan kadar fenol yang berbeda nyata dibandingkan pati alami maupun $\mathrm{HMT}_{23}$ (Tabel 2). Walaupun kadar fenol pati HMT secara statistik tidak berbeda nyata, tetapi kadar fenolnya cenderung menurun seiring meningkatnya kadar air awal pati. Rendahnya kadar fenol HMT disebabkan karena fenol dalam air akan terionisasi dan adanya pemanasan menyebabkan terjadi degradasi kadar fenol. Semakin tinggi kadar air awal pada saat memodifikasi pati menggunakan HMT menyebabkan terjadi penurunan kadar fenol pati. Fares et al. (2008) melaporkan bahwa total fenol menurun secara signifikan diakibatkan terjadinya degradasi oksidatif dengan adanya oksigen, air dan pemanasan. Ketersediaan air pada pati $\mathrm{HMT}_{33}$ pada saat pemanasan, menyebabkan degradasi oksidatif lebih berpeluang terjadi dibandingkan dengan pati alami ataupun $\mathrm{HMT}_{23}$ dan $\mathrm{HMT}_{28}$. Hal ini yang menyebabkan menurunnya kadar fenol pati $\mathrm{HMT}_{33}$ lebih tinggi dibandingkan perlakuan lainnya.

\section{Kadar pati resisten}

Tinginya RS pati sagu ihur alami (6,5\%) atau rendahnya kedapatcernaan pati sagu berhubungan dengan kristalinitas pati dan juga dipengaruhi oleh keberadaan senyawa fenolik yang terdapat pada granula pati. Kadar total fenol pati sagu ihur adalah 7,91. Senyawa fenol dapat menghambat aktivitas enzim pencernaan, sehingga bertanggung jawab terhadap resistensi pati sagu terhadap agen penyebab degradasi. Kadar RS pati sagu HMT $(5,4-$ $6,1 \%)$ lebih rendah dibandingkan pati alaminya (Tabel 2). Hasil yang relatif sama juga ditunjukkan oleh Chung et al. (2009) dan Kim dan Huber (2013), kadar RS beberapa jenis pati HMT mengalami penurunan setelah modifikasi dibandingkan pati alaminya. Hal ini dapat disebabkan karena perubahan struktur molekul yang menyebabkan kerusakan ikatan heliks ganda yang membentuk daerah kristalin. Selanjutnya Kim dan Huber (2013) mengemukakan bahwa semakin tinggi kadar air awal untuk perlakuan HMT $\left(\mathrm{HMT}_{15}, \mathrm{HMT}_{20}\right.$ dan $\left.\mathrm{HMT}_{25}\right)$ sangat memengaruhi perubahan kristalinitas pati kentang HMT. Rendahnya kadar amilosa juga turut mempengaruhi kadar RS.

\section{KESIMPULAN}

Perlakuan modifikasi pati sagu ihur dengan teknik HMT pada kondisi pemanasan $110^{\circ} \mathrm{C}$ selama 4 jam dengan pengaturan kadar air (23, 28, atau $33 \%$ ) menyebabkan perubahan karakteristik fisikokimia dan fungsional pati HMT yang dihasilkan, yaitu mengubah warna, menurunkan kemampuan menggelembung pati, kejernihan pasta, kadar amilosa, 
fenol dan kadar pati resisten. Perlakuan modifikasi HMT juga meningkatkan daya larut pati dan kadar air.

\section{DAFTAR PUSTAKA}

Andrade MMPA, de Oliveira CS, Colman TAD, da Costa FJOG, Schnitzler E. 2014. Effects of heatmoisture treatment on organic cassava starch. J Therm Anal Calorim 115: 2115-2122. DOI: 10.10 07/s 10973-013-3159-3.

[AOAC] Association of Official Analytical Chemists. 1984. Official Methods of Analysis of The Association of Official Analytical Chemists. $14^{\text {th }}$ Ed. AOAC Inc. Arlington, Virginia.

[AOAC] Association of Official Analytical Chemists. 2007. Official Methods of Analysis of The Association of Official Analytical Chemists, $18^{\text {th }} \mathrm{Ed}$. Washington DC.

Adebowale KO, Henle T, Schwarzenbolz U, Doert T. 2009. Modification and properties of African yam bean (Sphenostylis stenocarpa Hochst. Ex $A$. Rich.) Harms starch I: Heat moisture treatments and annealing. Food Hydrocolloid 23: 19471957. DOI: 10.1016/j.foodhyd.2009.01.002.

Balasubramanian S, Sharma R, Kaur J, Bhardawaj N. 2014. Characterization of modified pearl millet (Pennisetum typhoides) starch. J Food Sci Technol 51: 294-300. DOI: 10.1007/s13197-0110490-1.

Chung HJ, Hoover R, Liu Q. 2009. The impact of single and dual hydrothermal modifications on the molecular structure and physicochemical properties of normal corn starch. Int $\mathrm{J}$ Biol Macromol 44: 203-210. DOI: 10.1016/j.ijbiomac. 2008.12.007.

Collado LS, Corke H. 1999. Heat moisture treatment effects on sweet potato starches differing in amylose content. Food Chem 65: 339-346. DOI: 10.1016/S0308-8146(98)00228-3.

Fares C, Codianni P, Nugro F, Platani C, Scazzina F, Pellegrini N. 2008. Processing and cooking effects on chemical, nutritional and functional properties of pasta obtained from selected emmer genotypes. J Sci Food Agr 88: 24352444. DOI: $10.1002 /$ jsfa.3350.

Gunaratne A, Hoover R. 2002. Effect of heat-moisture treatment on the structure, and physicchemical properties of tuber and root starches. Carbohydr Polym 49: 425-437. DOI: 10.1016/SO 144-8617(01)00354-X.

Gunorubon AJ, Kekpugile DK. 2012. Modification of cassava starch for industrial uses. Int $\mathrm{J}$ Eng Technol 2: 913-919.
Haryani K, Hadiyanto, Hargono NA, Handayani. 2015. Sifat Fisikokimia Pati Sorghum Varietas Merah dan Putih Termodifikasi Heat Moisture Treatment (HMT) untuk produk Bihun Berkualitas. Prosiding Seminar Nasional Teknik Kimia "Kejuangan": Pengembangan Teknologi Kimia untuk Pengolahan Sumber Daya Alam Indonesia. Yogyakarta, 18 Maret 2015.

Hoover R, Manuel. H. 1996. Effect of heat-moisture treatment on the structure and physicochemical properties of legume starches. Food Res Int 29: 731-750. DOI: 10.1016/S0963-9969(97)868731.

Jiranuntakul W, Puttanlek C, Rungsardthong V, Puncha-arnon S, Uttapap D. 2011. Microstructural and physicochemical properties of heatmoisture treated waxy and normal starches. J Food Eng 104: 246-258. DOI: 10.1016/j.jfood eng.2010.12.016.

Kim JY, Huber KC. 2013. Heat moisture treatment under mildly acidic conditions alters potato starch physicochemical properties and digestibility. Carbohyd Polym 98: 1245-1255. DOI: 10.10 16/j.carbpol.2013.07.013.

Lang ATP, Mohamed AMD, Karim AA. 2006. Sago starch and composition of associated components in palms of different growth stages. Carbohyd Polym 63: 283-286. DOI: 10.1016/j. carbpol.2005.08.061.

Li S, Ward R, Gao Q. 2011. Effect of heat-moisture treatment on the formation and physicochemical properties of resistant starch from mung bean (Phaseolus radiatus) starch. Food Hydrocolloid 25: 1702-1709. DOI: 10.1016/j.foodhyd.2011.03. 009.

Malumba $P$, Janas $S$, Roiseux $O$, Sinnaeve $G$, Masimango T, Sindic M, Deroanne C, Bera F. 2010. Comparative study of the effect of drying temperatures and heat-moisture treatment on the physicochemical and functional properties of corn starch. Carbohyd Polym 79: 633-641. DOI: 10.1016/j.carbpol.2009.09.013.

Mayer AM. 1986. Polyphenol oxidases in plants recent progress. Phytochem 26: 11-20. DOI: 10.1016/S0031-9422(00)81472-7.

Nadir AS, Helmy IMF, Nahed M, Abdelmaguid, Wafaa MM, Abozeid, Ramadan MT. 2015. Modification of potato starch by some different physical methods and utilization in cookies production. Int J Curr Microbiol App Sci 4: 556569.

Olayinka OO, Adebowale KO, Owolubi BIO. 2008. Effect of heat moisture treatment on physicochemical properties of white sorghum starch. Food Hydrocolloid 22: 225-230. DOI: 10.10 16/j.foodhyd.2006.11.004. 
Polnaya FJ, Talahatu J, Haryadi, Marseno DW. 2009. Karakterisasi tiga jenis pati sagu (Metroxylon sp.) hidroksipropil. Agritech 29: 8795. DOI: 10.22146/agritech.9768.

Pranoto Y, Rahmayuni, Haryadi, Rakshit SK. 2014. Physicochemical properties of heat moisture treated sweet potato starches of selected Indonesian varieties. Int Food Res J 21: 2031-2038.

Pukkahuta C, Varavinit S. 2007. Structural transformation of sago starch by heat-moisture and osmotic-pressure treatment. Starch-starke 59: 624-631. DOI: 10.1002/star.200700637.

Puncha-arnon S, Uttapap D. 2013. Rice starch vs. rice flour: Differences in their properties when modified by heat-moisture. Carbohyd Polym 91: 85-91. DOI: 10.1016/j.carbpol.2012.08.006.

Purwani YE, Widaningrum, Thahir R, Muslich. 2006. Effect of heat moisture treatment of sago starch on its noodle quality. Indonesian $\mathrm{J}$ Agric Sci Indonesian 7: 8-14.

Rahmayuni. 2009. Perbaikan Karakteristik Pati Ubi Jalar dengan Heat Moisture Treatment untuk Pembuatan Starch Noodle. [Tesis]. Fakultas Teknologi Pertanian. Universitas Gadjah Mada Yogyakarta.

Rodríguez-Carpena JG, Morcuende D, Andrade MJ, Kylli P, Estévez M. 2011. Avocado (Persea americana Mill.) phenolics, in vitro antioxidant and antimicrobial activities, and inhibition of lipid and protein oxidation in porcine patties. J Agr Food Chem 59: 5625-5635. DOI: 10.1021/jf1048 832.
Singh $H$, Chang $H Y$, Lin $H J$, Singh $N$, Singh $N$. 2011. Influence of heat-moisture treatment and annealing on functional properties of sorghum starch. Food Res Int 44: 2949-2954. DOI: 10.10 16/j.foodres.2011.07.005.

Sun Q, Zhu Z, Si F, Xiong L. 2015. Effect of acid hydrolysis combined with heat moisture treatment on structure and physicochemical properties of corn starch. Food Sci Technol 52: 375382. DOI: 10.1007/s13197-013-0998-7.

Syamsir E, Hariyadi P, Fardiaz D, Andarwulan N, Kusnandar F. 2012. Pengaruh proses heatmoisture treatment (HMT) terhadap karakteristik fisikokimia pati. J Teknol Industri Pangan 23: 100-106.

Waliszewski, KN, Aparicio, MA, Bello, LA, Monroy, JA. 2003. Changes of banana starch by chemical and physical modification. Carbohyd Polym 52: 237-242. DOI: 10.1016/S0144-8617(02)00 270-9.

Yadav SB, Guleria P, Yadav BR. 2013. Hydrothermal modification of indian water chesnut: Influence of heat-moisture treatment and annealing on the physicochemical, gelatinization and pasting characteristics. LWT-Food Sci Technol 53: 211-217. DOI: 10.1016/j.Iwt.2013. 02.007 .

Zavareze RDE, Storck RC, Castro de SAL, Schirmer, AM, Dias, GRA. 2010. Effect of heatmoisture treatment on rice starch of varying amylose content. Food Chem 121: 358-365. DOI: 10.1016/j.foodchem.2009.12.036. 